\title{
Analysis of the Socioeconomic Conditions and Satisfaction Level of Beneficiaries of the Samurdhi Poverty Alleviation Program in Sri Lanka
}

\author{
Bandara, B.G.L.R.N.S • Hwang, Han-Cheol \\ The Graduate School of International Development and Cooperation, Hankyong National University \\ *Dept. of Biosciences \& Rural Systems Engineering, Hankyong National University

\section{스리랑카 사무르디 빈곤퇴치프로그램 수혜자의 사회경제적 조건과 만족도 분석} \\ 반다라・황한철*
}

한경대학교 국제개발협력대학원 • ${ }^{*}$ 한경대학교 지역자원시스템공학과

\begin{abstract}
요 약 : 사무르디는 스리랑카의 빈곤퇴치를 위한 프로그램 중 가장 규모가 큰 사회복지 지원 사업으로 1995년 청년, 여성, 장애인 등의 취업기회의 제공과 역량을 제고하여 궁극적으로 국가의 빈곤을 퇴치하고자 중앙정부에 의해 마련되었다. 본 연 구는 사무르디 프로그램 수혜자의 만족도를 높이기 위한 사회경제적 관련 인자들이 무엇인지를 밝히고자 하였다. 사례연구 지역은 스리랑카 중부지역에 위치한 오지이며 빈곤도가 높아 본 프로그램의 수혜율이 비교적 높은 캔디(Kandy) 지역을 대 상으로 하였다. 본 프로그램의 주목적인 소득향상을 비롯하여 훈련프로그램, 사무르디은행의 신용, 정부보조금, 보험금, 기술 정보제공, 마케팅시설, 고용기회제공, 도로개발, 관개수로시설 및 공공기반시설 등 프로그램의 지원내용 등과 관련된 다양한 인자들을 대상으로 수혜자의 만족도는 물론 이에 영향을 미치는 사회경제적 인자의 특성 등을 밝히고자 하였다. 다단계 표 본 추출방법으로 150 사무르디프로그램 수혜자를 선정하여 관련 설문조사를 실시하였으며(유효설문 127), SAS9.1 통계분석 용 소프트웨어를 사용하여 빈도분석, 회귀분석 등을 실시하였다. 그 결과 사무르디 수혜자들은 정부보조 및 사무르디 은행 의 신용 제공, 보험금 지급, 도로개발, 소득 증대 등에 대해서는 만족도가 매우 높은 반면 종자나 비료 등의 농업투입요소나 마케팅시설, 기술정보 제공 등에 대해서는 비교적 낮은 만족도를 보였다. 회귀분석 결과 사무르디 프로그램 실시 후 소득 증대, 고용 기회와 훈련프로그램 제공, 사무르디 은행의 신용 제공 등이 중요한 요인임을 확인할 수 있었다. 본 사무르디 프 로그램을 통하여 지역주민의 생활여건 개선은 물론 소득을 향상시켜 나아가 빈곤 퇴치라는 본래의 취지와 역할을 제대로 수행하기 위해서는 농업인 조직 강화, 농산물집하시설 등 마케팅 및 유통 시설 확충, 농기계 지원, 농업생산시설 등을 지속 적으로 확충하여야 할 것이며, 정부의 지속적인 모니터링과 평가 등을 통하여 사무르디 프로그램을 보다 긍정적으로 발전시 켜 나가야 할 것이다.
\end{abstract}

핵심용어 : 사무르디 프로그램, 빈곤퇴치, 수혜자 만족도, 사회경제적 조건.

\section{Introduction}

Sri Lanka has shown impressive progress in reducing the incidence of poverty and in achieving high levels of human development indicators since its independence

Corresponding author : Hwang, Han-Cheol

Tel : 031-670-5133

E-mail : hwang@hknu.ac.kr
(Kelegama, 2003). Despite these efforts and significant progress in human development indicators, the incidence of poverty in the country has remained high over the past several decades. Currently, about $7.2 \%$ of the population live below the poverty line (Central Bank Annual Report, 2011). Further, considerable variation in poverty levels can be observed across sectors and districts in Sri Lanka. Since more than $85 \%$ of the population still lives in rural areas and estate sectors, Sri Lankan poverty is often described as 
rural poverty (DCS, 2009/2010).

Furthermore, the latest calculation of the poverty headcount ratio (HCR) shows that the poverty rate of the country has further declined from $15.2 \%$ reported in 2006 - 07 to $8.9 \%$ in $2009-10$. The $41 \%$ reduction reported in just 3 years has been the highest drop ever witnessed, and the previous high was a drop of exactly one third, from $22.7 \%$ to $15.2 \%$, reported over the 4.5 -year period from the 2002 survey period to the 2006-07 survey period (DCS, 2010). The decline in poverty is significant in the estate and rural sectors, while the decline in urban poverty is moderate (Central Bank Annual Report, 2010). Neither the economic growth rate nor its distributional effects during the past three decades have been sufficient to bring about a significant reduction in poverty levels in the country. Moreover, the civil war that lasted for more than 30 years had caused immense human suffering and deprivation. Low productivity in the agricultural sector, poor infrastructure facilities and limited access to basic social services in rural areas, labor market distortions, lack of positive attitude, low level of education, poor income level, malnutrients, poor saving, and exogenous negative shocks such as lack of government support, credit facilities natural disasters as drought, flood have also contributed to the high incidence of poverty in Sri Lanka.

Poverty can be identified as the major problem that has received the attention of planners and policy makers in Sri Lanka since independence in 1948. Therefore, the various governments of Sri Lanka have initiated a number of antipoverty programs, such as Janasaviya, Food Stamp program, a school midday meal program, Gamidiriya, and the Samurdhi program etc. Although many resources have been invested in these programs, the results were not commensurate with the investments and the problem of poverty hard to eliminate totally.

In this background, the aim of my study is a proper analysis of the beneficiary's satisfaction with the Samurdhi program, analysis that plays a role in better understanding of the present state of the Samurdhi program. It is known that the beneficiary's satisfaction is correlated with several factors, like personal background, education level, government supporting services, and some socioeconomic factors. Furthermore, it is necessary to identify the relation between those factors and the beneficiary's satisfaction. It will help the Samurdhi program fully achieve its goals in the future and for politicians to generate efficient and effective poverty alleviation rural development programs in the future.

\section{The Samurdhi Welfare Poverty Alleviation Program}

\section{Outline of the Program}

With the political change in 1994, a new island wide poverty alleviation program named Samurdhi was introduced in 1995. Samurdhi is a national program of poverty alleviation in Sri Lanka under the Samurdhi Authority (MoYASRD, 1994). The objectives of this program are to find a solution for poverty. It is not an easy task, but through the Samurdhi program, priority has been given to activities such as development of rural infrastructure facilities; improvement of health and nutritional conditions in rural communities; integration of youth, women, and disadvantaged groups into economic and social development activities; promotion of social stability; and alleviation of poverty by the enhancement of access to opportunities for self-employment among households and promoting savings amongst them (Samurdhi Authority of Sri Lanka, 1998).

From its inception in 1995, Samurdhi program coverage had increased to 1.6 million households by the end of 2008 (Central Bank Annual Report, 2008). In response to a request by the government, the World Bank has been providing non-lending technical assistance for Samurdhi welfare reform since 2003. This World Bank technical assistance has consisted of two major components: (1) a reorientation in the selection of program beneficiaries from subjective eligibility criteria to a formula-based system that allows for greater objectivity and (2) the creation of the institutional capacity to support the changes in the selection process. A change in government in March 2004 altered the pace and sequence of the steps in the implementation (World Bank, 2007)

\section{Components of the Program}

The Samurdhi program consists of three components. The consumption grants transfer to eligible households, the first component of the program, is the largest, claiming 
around $80 \%$ of the program's budget (Samaratunga and Thibbotuwawa, 2009). The second is a savings and credit program operated through Samurdhi banks, with loans meant for entrepreneurial and business development. The third component is rehabilitation and development of community infrastructure through "workfare" and social or human development programs, including community mobilization and beneficiary participation (Gunetilleke , 2000).

Samurdhi has also established a social insurance program, where the beneficiaries of the highest consumption grants pay premiums to finance a social insurance program available to all eligible households. Further, the same beneficiaries contribute $20 \%$ of the value of their stamps in lieu of forced savings. These savings are unavailable for withdrawal for five years (Ismail and Samankantha, 2008).

\section{Beneficiaries' Selection}

Beneficiary eligibility is determined by individual assessment of the means (income) of intended beneficiaries. If an applicant's income falls below a certain threshold, that person is eligible for the program. In 1999, the eligibility criterion has been increased up to SLRs1,500 (combined household income) per month from SLRs1,000 in 1998 .

The beneficiaries of the Samurdhi program receive a monthly food stamp payment between SLRs100 and 1,000, depending on household income and household size. The beneficiaries of the Samurdhi program receive a monthly food stamp payment of between SLRs 100-1,000, depending on household income and household sizes. Food stamp grants were increased several times and each food stamp group (FSG) includes different amounts of welfare, forced savings, and social security grants(Ismail and Samankantha, 2008).

\section{Administrative Structure of the Program}

The administration of the program is done by the Ministry of Economic Development. Three departments within the ministry coordinate various Samurdhi functions: the Department of Poor Relief, the Department of the Commissioner General of Samurdhi, and the Samurdhi Authority. There are district, divisional, and zonal-level
Samurdhi authorities. The administrative structure of the Samurdhi program extends from a few key national bodies right down to village-level animators or development officers.

The grassroots-level officers are called Samurdhi development officers. The village requirement is decided at village meetings. Meeting participants are beneficiaries, government officers, and village political and religious leaders. Samurdhi program progress is reviewed at the monthly meeting.

\section{Community Participation}

Social mobilization and training activities have played important roles in bringing about community involvement and, eventually, people empowerment. As the program is anchored in participatory development principles, communities and beneficiaries are encouraged to be involved in various aspects of the program for management, planning, and monitoring, as most of the activities take place in the village and cluster levels.

\section{Research Methodology}

The study was carried out in the Kandy District which is located in the central province of Sri Lanka, and three study areas were located in the Hatharaliyadda, Thumpane (Galagedara) and Harispaththuwa Divisional Secretariat(DS) divisions because of relatively higher proportion(38\%) of Samurdhi beneficiaries by national level (DCS, 2010).

For the study, beneficiaries' satisfaction and FSGs were considered as the dependent variables. Major independent variables were selected: the socio-descriptive, economic, and personal categories. In addition, a number of independent variables that come under the major categories were identified as independent variables.

Primary data for the study were collected by using structured questionnaires and personal interviews. The questionnaire was developed by referring to questionnaires that had been successfully used on previous occasions. In addition, the questionnaire was pretested and modified before the start of data collection in the selected field. The related secondary data were collected directly from relevant institutions. 
The respondents were selected by using a multistage sampling design. The sample household respondents (150) were selected randomly and 127 respondents were available.

Both descriptive and statistical methods, such as frequency analysis, chi-square test and regression analysis using SAS 9.1 statistical program, were used to analyze the collected data.

\section{Results and Discussion}

\section{Analysis of Respondents' Satisfaction with Samurdhi Program}

The main thrust embodied in the Samurdhi program is to ensure the participation of the Samurdhi beneficiaries by increasing accessibility of resources for self-employment, social security, enhanced health and nutritional status, and improved rural infrastructure. In addition, the Samurdhi bank provides low-interest loans for beneficiaries' livelihood activities and uplifting of their living standard by reconstruction, improvement, and electrification of houses and by awareness programs. The respondents' satisfaction, a dependent variable, was measured by using a series of questions that had been pretested and corrected to get the maximum results. By considering these things, respondents' satisfaction with the Samurdhi program was evaluated by using 15 variables and a 5-level Likert scale of satisfaction. Results are shown in Table 1 and Figure 1.

According to the Likert values of the study, the majority of the respondents are more highly satisfied with credit provided by the Samurdhi bank (4.40) and subsidies provide by the government (4.45), such as low-interest-rate bank loans not only for self-employment, but also for improving their living standard; subsidies provided by the government for electricity, kerosene, meals, and a milk program for schoolchildren and pregnant women to overcome malnutrition problems in Samurdhi families.

In addition, according to the information revealed by the respondents and the Likert values for increased income under the Samurdhi program, training provided by the program, the social security scheme, employment opportunities created by the Samurdhi program, social security payments for childbirth, illness, marriage, and death of family members, road development after the Samurdhi program was implemented, value of food stamps, technical information provided, minor irrigation, and community facilities development under the Samurdhi

Table 1 Frequency, Likert values and ranks of satisfaction variables

\begin{tabular}{|c|c|c|c|c|c|c|c|c|}
\hline \multirow{2}{*}{ Variable } & \multicolumn{5}{|c|}{ Frequency* } & \multirow{2}{*}{ Total } & \multirow{2}{*}{$\begin{array}{c}\text { Likert value } \\
\text { (Average) }\end{array}$} & \multirow{2}{*}{ Ranl } \\
\hline & 1 & 2 & 3 & 4 & 5 & & & \\
\hline 1. Increase income & 0 & 2 & 23 & 64 & 38 & 127 & 4.09 & 5 \\
\hline 2. Amount of food stamp & 3 & 2 & 28 & 56 & 38 & 127 & 3.98 & 9 \\
\hline 3. Training & 0 & 8 & 33 & 37 & 49 & 127 & 4.00 & 8 \\
\hline 4. Credit provided by the Samurdhi bank & 0 & 2 & 14 & 42 & 69 & 127 & 4.40 & 2 \\
\hline 5. Input supply & 1 & 15 & 54 & 37 & 20 & 127 & 3.47 & 13 \\
\hline 6. Technical information provided & 2 & 6 & 52 & 46 & 21 & 127 & 3.61 & 12 \\
\hline 7. Marketing facilities provided & 4 & 39 & 54 & 23 & 7 & 127 & 2.92 & 14 \\
\hline 8. Input availability & 6 & 45 & 46 & 17 & 13 & 127 & 2.89 & 15 \\
\hline 9. Social security scheme & 3 & 3 & 30 & 34 & 57 & 127 & 4.09 & 5 \\
\hline 10. Employment opportunities & 0 & 6 & 37 & 30 & 54 & 127 & 4.04 & 7 \\
\hline 11. Insurance Payment & 3 & 0 & 27 & 35 & 62 & 127 & 4.20 & 3 \\
\hline 12. Subsidies provided by the Government & 0 & 3 & 16 & 29 & 79 & 127 & 4.45 & 1 \\
\hline 13. Road development & 0 & 2 & 30 & 43 & 52 & 127 & 4.14 & 4 \\
\hline 14. Minor irrigation development & 1 & 4 & 40 & 37 & 45 & 127 & 3.95 & 10 \\
\hline 15. Community facilities development & 3 & 3 & 46 & 25 & 50 & 127 & 3.91 & 11 \\
\hline
\end{tabular}

* A rank of Likert value: 5: Strong satisfied 4: Satisfied 3: Moderately satisfied 2: Unsatisfied

1: Strongly unsatisfied 


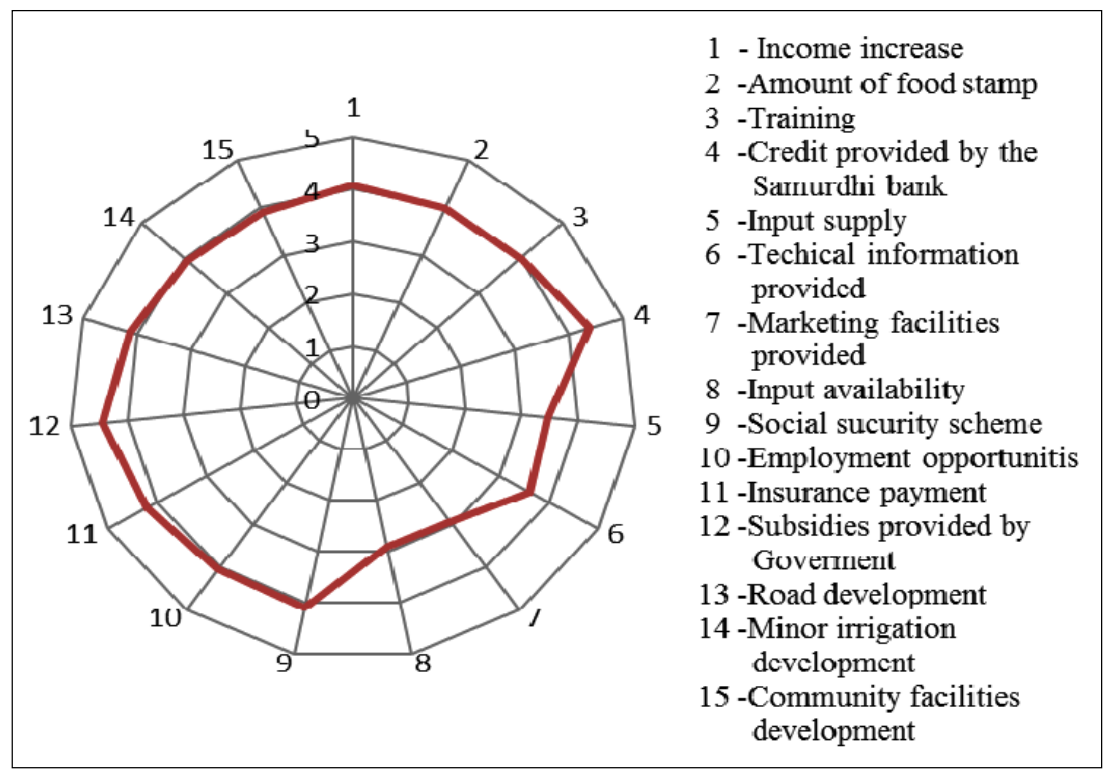

Figure 1 Likert values of satisfaction variables of the study.

program, these are also categorized as satisfied because of Likert values between 3.5 and 4.5 .

\section{Analysis of the Relationship between Socio- economic Characteristics of the Respondents}

Identified independent variables were analyzed with identified dependant variables using linear regression models. Four vital dependent variables among many independent variables were identified by considering the objective of the Samurdhi program which is mainly focusing on creating opportunities, empowerment and mobilization of the beneficiaries. Therefore, income increased after Samurdhi program, employment opportunities, training, and credit provided by the Samurdhi programs were recognized as depended variable for Multiple Linear Regression(MLR). Four regressions were run with each identified dependant variable and identified independent variables.

Table 2 summarized the results of all regressions of the study. According to the results, awareness programs have a significant positive relationship with income increased after Samurdhi program and credit provided by the Samurdhi bank while it has a significant negative relationship with training provided by the Samurdhi program and no significant relationship with employment opportunities provided by the Samurdhi program.
Income increased after Samurdhi program and credit facilities provided by the Samurdhi program show a significant positive relationship with training provided by the Samurdhi program while technical information and marketing facilities provided by the Samurdhi program, and eradicate malnutrition among children's of the Samurdhi families have a significant positive and input availability has a significant negative relationship with employment opportunities provided by the Samurdhi program and no significant relationship with other dependents.

Respondents who are participating in the training programs provided by the Samurdhi has a significant positive relationship with income increases after Samurdhi program and credit facility provided by the Samurdhi bank while the amount of food subsidy of the food stamps has a significant positive and negative relationship with income increases after Samurdhi program and employment opportunities provided by the Samurdhi program respectively. Community development on the village with Samurdhi program has a significant negative and positive relationship with income increased after Samurdhi program and employment opportunities provided by the Samurdhi program respectively while road development with Samurdhi program has a significant positive relationship with income increased after Samurdhi program and no significant relationship with another three dependent factor.

Moreover, the results of the study show that Samurdhi 
Table 2 Relationship between socio-economic characteristics by Multiple Linear Regressions (MLR)

\begin{tabular}{|c|c|c|c|c|}
\hline \multirow[b]{2}{*}{ Model } & $\begin{array}{l}\text { Income } \\
\text { increase }\end{array}$ & $\begin{array}{l}\text { Employment } \\
\text { opportunities }\end{array}$ & Training provided & Credit provided \\
\hline & $\begin{array}{c}\text { Standardized } \\
\text { Coefficients } \\
\text { Beta } \\
\end{array}$ & $\begin{array}{c}\text { Standardized } \\
\text { Coefficients } \\
\text { Beta }\end{array}$ & $\begin{array}{l}\text { Standardized } \\
\text { Coefficients } \\
\text { Beta }\end{array}$ & $\begin{array}{l}\text { Standardized } \\
\text { Coefficients } \\
\text { Beta } \\
\end{array}$ \\
\hline Income increased by Samurdhi & - & .141 & $.295^{* *}$ & -.040 \\
\hline Amount of food subsidy & $.282^{* *}$ & $-.259^{* *}$ & .109 & .118 \\
\hline Trainings provided & $.345^{* *}$ & .155 & - & $.233^{*}$ \\
\hline Credit provided & -.040 & .083 & $.200^{*}$ & \\
\hline Input supply & -.028 & -.083 & .041 & -.007 \\
\hline Technical information provided & -.004 & $.238^{* *}$ & .012 & -.019 \\
\hline Marketing facilities & -.088 & $.154^{*}$ & -.019 & -.015 \\
\hline Input availability & .140 & $-.170^{*}$ & .056 & .095 \\
\hline SSWS $^{* * *}$ & -.007 & $.225^{* *}$ & -.179 & $-.208^{*}$ \\
\hline Employment opportunities & .215 & - & .202 & .125 \\
\hline Social security payments & .134 & $-.178^{*}$ & -.045 & $.267^{*}$ \\
\hline Low interest rate loan provided & .063 & -.093 & -.107 & $.419^{* *}$ \\
\hline Awareness programs & $.204^{*}$ & -.112 & $-.204^{*}$ & $.313^{* *}$ \\
\hline Road development program & $.354^{* *}$ & .060 & .110 & -.171 \\
\hline Minor irrigation development & -.060 & .171 & .168 & -.082 \\
\hline Community development & $-.433^{* *}$ & $.227^{*}$ & .044 & .055 \\
\hline Eradicate malnutrition & .001 & $.214^{*}$ & -.065 & -.101 \\
\hline Education level affected & .022 & .062 & -.021 & $.226^{*}$ \\
\hline Increase children's education & .034 & $-.231^{*}$ & .136 & $-.298^{*}$ \\
\hline New income generation & -.061 & $.343^{* *}$ & $.261^{* *}$ & .030 \\
\hline $\begin{array}{c}\text { Multiple } \mathrm{R}^{2} \\
\mathrm{~F} \text { Ratio }\end{array}$ & $\begin{array}{c}0.585 \\
7.950^{* *} \\
(\mathrm{~N}=127) \\
\end{array}$ & $\begin{array}{c}0.728 \\
15.062^{* *} \\
(\mathrm{~N}=127)\end{array}$ & $\begin{array}{c}0.646 \\
10.258^{* *} \\
(\mathrm{~N}=127) \\
\end{array}$ & $\begin{array}{c}0.587 \\
8.019^{* *} \\
(\mathrm{~N}=127) \\
\end{array}$ \\
\hline
\end{tabular}

* Significant at 0.05 level, ${ }^{* *}$ Significant at 0.01 level

*** SSWS: Samurdhi social security welfare scheme

social security welfare scheme (SSWS) has a significant positive and negative relationship with employment opportunities provided by the Samurdhi program and credit facility provided by Samurdhi bank respectively while social security payments show a significant negative and positive relationship with employment opportunities provided by the Samurdhi program and credit facility provided by Samurdhi bank respectively. Furthermore, Low interest rate loan provided by the Government and education level affected to increase family income show a strong positive relationship with the credit facility provided by Samurdhi bank.

In addition, Create new income generation projects of the respondent has a significant positive relationship with employment opportunities provided by the Samurdhi program and training provided by the Samurdhi program. However, increase children education of the respondents' families by Samurdhi program has a significant negative relationship with employment opportunities provided by the Samurdhi program and credit facility provided by Samurdhi bank.

In contrary, the results of the study reveal that the input supply, technical, employment opportunities provide by the Samurdhi program and minor irrigation development by the Samurdhi program have no significant relationships with these identified satisfaction factors.

\section{Conclusion and Recommendation}

It was applied to determine the Samurdhi beneficiary's socioeconomic condition and beneficiaries' satisfaction by increasing their income and increasing their socioeconomic and living standards through livelihood, infrastructure, and spiritual development through the Samurdhi poverty alleviation program. Samurdhi has effectively contributed 
toward poverty reduction in rural communities in Sri Lanka.

It was observed that the majority of the respondents are satisfied with income generation activities such as training, employment opportunities, insurance, food stamps and infrastructure development while they are high (strongly) satisfied with credit provided by the Samurdhi bank and government subsidies which have strongly helped them improve their living standards. But most of the beneficiaries are moderately satisfied with input supply, marketing facilities provided by the Samurdhi program and input availability for the income generation programs. In addition, results of regression reveal that, the many independent variables had a strong relationship with income increased after Samurdhi program, employment opportunities and training provided by the Samurdhi program, and credit provided by the Samurdhi bank.

Significant relationships were observed among identified dependant and independent variables, using multiple linear regression (MLR). Results of regressions reveal that there are strong significant relationships with income increase under the Samurdhi program, amount of food stamps, training provided by the Samurdhi program, credit provided by the Samurdhi bank, technical information provided, marketing facilities, input availability, the Samurdhi social security welfare scheme (SSWS), social security payments, low-interest-rate loans provided by the government, awareness programs organized by the Samurdhi program, the Samurdhi road development program, community facility development, help to eradicate malnutrition among the children of respondents families, help to increase children's education, and new income generation programs. In contrary, the results of the study reveal that input supply, employment opportunities provided by the Samurdhi program, and minor irrigation development by the Samurdhi program has no significant relationship with these identified satisfaction factors.

Therefore, government should be actively intervening in the supply of high-quality input and improvement of marketing facilities and input availability by the development of a better traffic network throughout the country. Strengthening of farmer reorganization, development of rural tourism, expanding marketing channels and collecting centers through the farmer organizations, reorganized small-scale producers with farmer organization, and providing farm and production machineries for farmer organizations are some of the possible solutions for input and marketing limitations in order to increase cultivation land and increase rural income by producing value-added products and handling bargaining power of the rural sector.

Continuous evaluation and monitoring of the Samurdhi program is necessary to increase the efficiency and productivity of the implementing programs. The Sri Lankan government has to improve capacity building and modernization skills of both the Samurdhi beneficiaries and government officers. Finally, the government needs to formulate anticorruption strategies to minimize corruption at field levels. By overcoming these identified limitations, Samurdhi program can be activated as a powerful tool for eradicating poverty and increase per capita GDB in Sri Lanka and living standard of the Samurdhi beneficiaries.

Since the study was limited to the selected three DS divisions in the province, and may not represent the whole province or the whole country, it is suggested that similar studies be conducted with wider geographical coverage. Since only a few variables in the study significantly affected the level of beneficiaries' satisfaction, similar studies using the other variables should be conducted to identify other predictive variables that were not addressed in this study. Such studies may further explain the remaining undetermined limitations and the levels of the beneficiaries' satisfaction.

\section{References}

1. Central Bank Annual Report, 2011,2010,2008, 1999, Sri Lanka.

2. DCS(Department of Census and Statistics), 2009/2010, Household Income and Expenditure Survey - Final Report, Ministry of Finance and Planning, Sri Lanka.

3. Glinskaya, Elena, 2000, "An Empirical Evaluation of the Samurdhi Program." Background paper for Sri Lanka: Poverty Assessment, Report 22535-CE (2002), Washington, DC, World Bank.

4. Gunetilleke, N., 2000, A note on the Sri Lankan experience in poverty reduction, Pakistan Institute of Development Economies, Islamabad, Pakistan, Volume: 39 Source Issue: 4.

5. Ismail, S. and Samankantha. J., 2008, Accelerating 
Rural Growth and Empowering the Rural Poor - The efficiency of the Samurdhi program in accelerating rural growth in Sri Lanka, 5th SAESM - University of Delhi.

6. Kelegama, S., 2003, "The Poverty Situation and Policy in Sri Lanka" in Christopher M. Edmonds (ed.), Reducing Poverty in Asia: Emerging Issues in Growth, Targeting and Measurement, Edward Elgar, U.K.

7. Lakshman, W.D., 2000, Income Distribution and Poverty, Sri Lanka Samurdhi Authority.

8. Ministry of Finance and Planning Sri Lanka (MFP), 2010, 2009, 2007, Annual Report.

9. Ministry of Youth Affairs, Sports and Rural Development, 1998, 'Samurdhi: National Programme for Poverty Alleviation', Monitoring and Evaluation Division, Samurdhi Authority of Sri Lanka.

10. Samaratunga, P. A., and Thibbotuwawa, M., 2009, Food security situation in Sri Lanka, Mimeo, Indian Council for Research on International Economic
Relations (ICRIER), New Delhi. India.

11. United Nations, 1997, Making an Impact: Innovative HRD Approaches to Poverty Alleviation, A BottomUp Approach towards Poverty Allevation - Attacking the poverty problem in Sri Lanka, ESCAP, HRD Section.

12. Word Bank, 2007, Sri Lanka Poverty Assessment Engendering Growth with Equity: Opportunities and Challenges, Report No. 36568, Poverty Reduction and Economic Management Sector Unit South Asia Region pp 1-74.

13. http://www.worldbank.org

14. http://www.samurdhi.gov.lk

15. http://www.statistics.gov.lk

접 수 일: (2013년 8월 22일)

수 정 일: (1차: 2013년 11월 25일, 2차: 12월 9일)

게재확정일: (2013년 12월 9일)

- 3인 익명 심사필 